\title{
Penguatan Pendidikan Agama Islam Melalui Hafalan Furudhul Ainiyah di SMP Nurul Jadid Paiton Sulistiawati
}

\author{
Pasca Sarjana Universitas Nurul Jadid (UNUJA)
}

ABSTRAK

\begin{abstract}
Abstrak: Penguatan Pendidikan Agama Islam Melalui Hafalan Furudhul Ainiyah di SMP Nurul Jadid Paiton. Penelitian ini bertujuan untuk mencari dan menggali informasi tentang penguatan pendidikan Agama Islam (PAI) melalui hafalan furudhul Ainiyah yang di laksanakan di SMP Nurul Jadid Paiton. Pendekatan penelitian ini adalah kualitatif dengan metode studi kasus, untuk mengungkapkan kenyataan-kenyataan yang terjadi secara intensif dan mendalam berkaitan dengan fenomena di atas. Tekhnik pengumpulan data dan informasi dilakukan melalui wawancara, observasi, studi dokumentasi, dan studi literatur. Temuan penelitian ini adalah 1).siswa atau siswi diwajibkan untuk menuntaskan beban hafalan Furudhul Ainiyah sebagai syarat ikut ujian semester ganjil maupun semester genap serta menjadi syarat untuk kenaikan kelas dan kelulusan. 2). pelaksanaan hafalan furudhul Ainiyah dilaksanakan pada hari kamis dan malam jum'at serta malam selasa, dan bisa juga dilakukan pada jam istirahat di hari biasa, 3). Penanggung jawab dan penerima setoran hafalan adalah guru PAI dan wali kelas masing-masing, 4). Bagi siswa maupun siswi yang tidak bisa baca tulis Al-qur'an tidak dikenai beban hafalan, namun mendapatkan pembinaan khusus terkait baca tulis Al-qur'an yang dilakukan oleh koordinator keagamaan siswa. 5). Materi hafalan meliputi materi Aqidah, Fiqih atau Amaliyah, dan Doa-doa harian untuk siswa atau siswi kelas VII dan VIII semerter 1 dan 2, sementara untuk kelas IX semester 1 dan 2 meliputi materi Al-Qur'an dan Fiqih. 6). (a). Kepala Sekolah, (b). Wakil Kepala Sekolah bagian kurikulum, (c). Koordinator kegiatan keagamaan siswa, (d). Tenaga pengajar/ guru PAI, (e). Wali kelas, (e). Koordinator keagamaan siswa, (f). Siswa.
\end{abstract}


Kata Kunci: Penguatan, Pendidikan Agama Islam (PAI), Furudhul Ainiyah, Sekolah.

\begin{abstract}
Abstract: Strengthening Islamic Religious Education Through Memorization of Furudhul Ainiyah at Nurul Jadid Paiton Junior

High School. This research is intended to search and information about the strengthening of Islamic religious education (PAI) through the recitation of furudhul Ainiyah which is carried out in Nurul Jadid Paiton Junior High School. The method of this research is by qualitative method with case study method, to express. That is more intense and deep with the above phenomenon. Technique of completion of data and information is done through interview, observation, study study, and literature study. The findings of this research are 1). Students or students are required to complete the recitation of Furudhul Ainiyah as a condition to take the odd semester and even semester exam and become a requirement for class and graduation increase. 2). the implementation of the furudhul Ainiyah memorization is performed on Thursday and Friday nights and Tuesday nights, and can also be done during normal day breaks, 3). The responsible and recipient of the rote deposit are PAI teachers and their homeroom teachers, 4). For students and students who can not read written Al-qur'an is not subject to rote burden, but get special coaching related to Al-Qur'an reading written by the religious coordinator of students. 5). Memory materials include Aqidah, Fiqih or Amaliyah materials, and daily prayers for students of VII and VIII semerter 1 and 2, while for classes IX semesters 1 and 2 cover the material of the Qur'an and Fiqh. 6). (a). Principal, (b). Vice Principal of the curriculum section, (c). Coordinator of students' religious activities, (d). Teacher / teacher of PAI, (e). Homeroom, (e). Student religious coordinator, (f). Student.
\end{abstract}


Keywords: Strengthening, Islamic Religious Education (PAI), Furudhul Ainiyah, School.

\section{PENDAHULUAN}

Dalam konteks Islam, pendidikan secara bahasa (lughatan) ada tiga kata yang digunakan. Ketiga kata tersebut, yaitu : 1) At-tarbiyah, 2) Alta'lim, dan 3) Al-ta'dib. Ketiga kata tersebut memiliki makna yang saling berkaitan saling cocok untuk pemaknaan pendidikan dalam Islam. Ketiga makna itu mengandung makna yang amat dalam, menyangkut manusia dan masyarakat serta lingkungan yang dalam hubungannya dengan Tuhan berkaitan dengan satu sama lain (Ramayulis: 22). ${ }^{1}$

At-tarbiyah (التربية) berakar dari tiga kata, yakni pertama, berasal dari kata rabba yarbu (يربو - ربا) yang artinya bertambah dan bertumbuh. Kedua, berasal dari kata rabiya yarbi (يربى - ربي) yang artinya tumbuh dan berkembang. Ketiga, berasal dari kata rabba yarubbu (بربو - رب) yang artinya memperbaiki, membimbing, menguasai, memimpin, menjaga dan memelihara. Al-ta'lim (التعليم) secara lughawy berasala dari kata fi'il tsulasi mazid biharfin wahid, yaitu 'allama yu 'allimu (يعلم - علم). Jadi 'alama (علم) artinya mengajar. Al-ta'adib (التأديب) berasal dari kata tsulasi maszid bihaijm wahid, yaitu ‘addaba yu ‘addibu (يأدب - أدب). Jadi ‘addaba artinya memberi adab.(Mundiri \& Zahra, 2017)

Menurut Miqdad Yelyin (seorang guru besar Islam ilmu sosial di universitas Muhammad bin Su'ud Riyad Saudi arabia) seperti yang dikutip oleh Munarji, pendidikan Islam adalah usaha menumbuhkan dan membentuk manusia muslim yang sempurna dari segala aspek yang bermacam macam seperi aspak kesehatan, akal, keyakinan, jiwa, kemauan, daya cipta dalam semua tingkat pertumbuhan yang disinari oleh cahaya

\footnotetext{
${ }^{1}$ Ramayulis, Ilmu Pendidikan Islam. (Jakarta : kalam mulia, 2002), 33
} 
yang dibawa oleh Islam dengan versi dan metode-metode pendidikan yang ada diantaranya (Munardji: 2004). ${ }^{2}$

Menurut (Zakiah Daradjat: 2011), Pendidikan Agama Islam adalah pendidikan dengan melalui ajaran-ajaran Islam, yaitu berupa bimbingan dan asuhan terhadap anak didik agar nantinya setelah selesai dari pendidikan ia dapat memahami, menghayati dan mengamalkan ajaranajaran Agama Islam yang telah diyakininya secara menyeluruh, serta menjadikan Agama Islam itu sebagai suatu pandangan hidupnya demi keselamatan dan kesejahteraan hidup di dunia maupun di akhirat kelak. ${ }^{3}$

Berdasarkan uraian diatas pada intinya, pendidikan Islam adalah usaha pendewasaan manusia seutuhnya (lahir dan batin) dalam arti tuntunan yang menuntut peserta didik untuk memiliki kemerdekaan berfikir, merasa, bertindak, dan berbicara serta percaya pada diri sendiri dengan penuh rasa tanggung jawab dalam setiap tindakan dan perilaku kehidupan sehari hari dengan berlandaskan ukuran-ukuran tertentu yang telah ditentukan dalam Agama Islam.(Baharun \& Mundiri, 2011)

Semntara itu, Pendidikan Agama Islam memiliki Tujuan, yaitu suatu kepribadian yang seluruh aspeknya dijiwai oleh ajaran Islam. Orang yang berkepribadian Muslim dalam Al-Quran disebut "Muttaqun”. Karena itu Pendidikan Islam berarti juga untuk pembentukan manusia yang bertaqwa. Pendidikan tersebut sesuai dengan pendidikan Nasional yang dituangkan dalam tujuan pendidikan nasional yang akan membentuk manusia pancasila yang bertakwa kepada Tuhan Yang Maha Esa (Zakiah Daradjat: 2011). ${ }^{4}$

Menurut Abdurrahman Saleh Abdullah mengatakan dalam bukunya “Educational Theory a Qur'anic Outlook”, yang dikutip Armai

\footnotetext{
${ }^{2}$ Munardji, ilmu pendidikan Islam,( Jakarta, PT. Bina ilmu, 2004), 7

${ }^{3}$ Zakiah Daradjat, Ilmu Pendidikan Islam, (Jakarta: PT Bumi Aksara, 2011), 86

${ }^{4}$ Zakiah Daradjat, 30.
} 
Arief bahwa pendidikan Islam bertujuan untuk membentuk kepribadian sebagai khalifah Allah swt. Atau sekurang-kurangnya mempersiapkan ke jalan yang mengacu kepada tujuan akhir. Tujuan Islam menurutnya dibangun atas tiga komponen sifat dasar manusia yaitu: 1) Tubuh 2) Ruh 3) Akal yang masing-masing harus dijaga (Armai Arief: 2002). ${ }^{5}$

Disamping itu Pendidikan Agama Islam memiliki ciri yang berorientasi makro, berskala universal, dan bersifat deduktif normatif. Sehingga ruang lingkup pendidikan Islam sangat luas, tidak hanya menyangkut landasan ideal dan dasar pendidikan Islam, melainkan secara operasional.

Dengan ruang lingkup yang sedemikian luas sebenarnya dalam Pendidikan Agama Islam diperlukan waktu yang banyak pula guna efisiensi dalam proses transformasi keilmuan, disamping itu juga eksistensi pendidikan Agama Islam saat ini tengah menghadapi gempuran globalisasi, modernisme, yang mana banyak nilai-nilai yang masuk tidak sesuai dengan tumtunan Agama Islam, hal ini kemudian menimbulkan berbagai macam masalah diantaranya masalah dekadensi moral peserta didik, penyalahgunaan narkoba, miras, pencurian dan tindakan asusila. Hal ini juga berimbas pada persepsi masyarakat bahwa mutu Pendidikan Agama Islam di sekolah sangatlah rendah.(Mundiri, 2012)

Berangkat dari permasalahan di atas terkait minimnya jumlah jam yang diberikan kepada Pendidikan Agama Islam, diperlukan sebuah inovasi dari guru PAI maupun lembaga pendidikan untuk mengatasi tidak optimalnya proses transformasi Pendidikan Agama Islam yang disebabkan oleh minimnya jumlah jam yang diberikan kepada mata pelajaran PAI di sekolah.

\footnotetext{
${ }^{5}$ Armai Arief, Pengantar Ilmu dan Metodologi Pendidikan Islam, (Jakarta: Ciputat
} Pers, 2002), 18-19. 


\section{METODE PENELITIAN}

Penelitian ini merupakan kajian analitis terhadap penguatan Pendidikan Agama Islam melalui hafalan Furudhul Ainiyah. Oleh sebab itu penelitian yang dilakukan oleh penulis adalah menggunakan pengdekatan penelitian kualitatif. pendekatan penelitian kualitatif adalah penelitian yang dimaksudkan untuk memahami fenomena tentang apa yang dialami oleh subjek penelitian, misalnya perilaku, persepsi, motivasi, tindakan dan lain-lain, secara holistik dan dengan cara deskripsi dalam bentuk kata-kata dan bahasa, pada suatu konteks khusus yang alamiah dan dengan memanfaatkan berbagai metode alamiah (Lexy J. Moleoang: 2000). ${ }^{6}$ Sementara metode penelitian ini adalah menggunakan metode study kasus (case study). Dengan menggunakan study kasus ini peneliti berharap dapat mengindentifikasi penguatan Pendidikan Agama Islam dengan hafalan Furudhul Ainiyah di SMP Nurul Jadid, sehingga dapat memberikan gambaran tentang penguatan Pendidikan Agama Islam melalui hafalan Furudhul Ainiyah.

Lokasi penelitian ini adalah SMP Nurul Jadid yang beralamat di desa Karanganyar, Kecamatan Paiton, Kabupaten Probolinggo. Sekolah tersebut merupakan sekolah yang berada di bawah naungan Pondok Pesantren Nurul Jadid dan merupakan salah satu sekolah unggulan di kabupaten Probolinggo yang mempunya visi “ Membentuk kepribadian mandiri; berbasis keluhuran akhlak; kedalaman ilmu; dan berwawasan kebangsaan", serta memiliki misi "meningkatkan kualitas keyakinan terhadap Islam ( Ahlussunnah Wal Jamaah), Membentuk kepribadian yang berakhlak luhur, Mengembangkan ilmu pengetahuan dan keterampilan, Meningkatkan kesadaran sebagai makhluk sosial dan berwawasan kebangsaan" yang memungkinkan penulis memperoleh data yang dibutuhkan dalam penelitian ini. Adapun yang menjadi subjek dalam

\footnotetext{
${ }^{6}$ Lexy J. Moleoang, Metodologi Penelitian Kualitatif, (Bandung: PT. Remaja Rosda Karya,2000), 6.
} 
penelitian ini adalah warga sekolah yang ada di SMP Nurul Jadid paiton. Subjeknya adalah sebagai berikut: (1). Kepala Sekolah, (2). Wakil Kepala Sekolah bagian kurikulum, (3). Koordinator kegiatan keagamaan siswa, (4). Tenaga pengajar/ guru PAI, (5). Wali kelas, (6). Siswa.

Teknik pengumpulan data yang digunakan dalam penelitian ini adalah teknik observasi, wawancara, studi dokumentasi dan studi literatur. Dalam penelitian ini, pengolahan data dan analisis data adalah melalui proses menyusun, mengkategorikan data, mencari kaitan isi dari berbagai data yang diperoleh dengan maksud untuk mendapatkan maknanya. Data yang diperoleh dan dikumpulkan dari responden melalui hasil wawancara, observasi dan studi dokumentasi dilapangan untuk selanjutnya dideskripsikan dalam bentuk laporan. 


\section{TEMUAN DAN PEMBAHASAN}

Berdasarkan hasil wawancara, observasi, dan kajian dokumentasi, bahwa di SMP Nurul Jadid paiton mewajibkan siswa atau siswinya untuk menghafal dan menyetorkan hafalan kepada guru PAI dan wali kelas masing-masing.

Adapun materi hafalan dapat dilihat pada table berikut:

Tabel: 1

\begin{tabular}{|c|c|c|c|c|c|}
\hline \multirow[b]{2}{*}{ Materi Kelas 1 (Semester I) } & \multicolumn{2}{|c|}{ Nilai } & \multirow[b]{2}{*}{ Tgl. } & \multirow[b]{2}{*}{ Bulan } & \multirow{2}{*}{$\begin{array}{c}\text { Paraf } \\
\text { Pembina }\end{array}$} \\
\hline & Tuntas & $\begin{array}{c}\text { Tidak } \\
\text { Tuntas }\end{array}$ & & & \\
\hline \multicolumn{6}{|l|}{ A. AQIDAH } \\
\hline \multicolumn{6}{|l|}{$\begin{array}{l}\text { - Siswa dapat menyebutkan tiga } \\
\text { pilar aqidah (Islam, Iman, Ihsan) }\end{array}$} \\
\hline \multicolumn{6}{|l|}{$\begin{array}{l}\text { - Siswa dapat menjelaskan } \\
\text { pengertian islam, iman, ihsan }\end{array}$} \\
\hline \multicolumn{6}{|l|}{$\begin{array}{l}\text { - Siswa dapat menghafal rukun } \\
\text { iman }\end{array}$} \\
\hline \multicolumn{6}{|l|}{$\begin{array}{l}\text { - Siswa dapat menjelaskan } \\
\text { pengertian iman kepada Allah }\end{array}$} \\
\hline \multicolumn{6}{|l|}{ B. FIQH/AMALIYAH } \\
\hline \multicolumn{6}{|l|}{$\begin{array}{l}\text { - Siswa dapat menjelaskan } \\
\text { pengertian thaharah }\end{array}$} \\
\hline \multicolumn{6}{|l|}{$\begin{array}{l}\text { - Siswa dapat menyebutkan } \\
\text { macam macam alat-alat bersuci }\end{array}$} \\
\hline \multicolumn{6}{|l|}{$\begin{array}{l}\text { - Siswa dapat menjelaskan } \\
\text { penggunaan alat-alat bersuci dan } \\
\text { syaratnya }\end{array}$} \\
\hline \multicolumn{6}{|l|}{$\begin{array}{l}\text { - Siswa dapat menjelaskan } \\
\text { pembagian hukum air }\end{array}$} \\
\hline \multicolumn{6}{|l|}{$\begin{array}{l}\text { - Siswa dapat menjelaskan syarat } \\
\text { debu yang bias dipakai bersesuci }\end{array}$} \\
\hline \multicolumn{6}{|l|}{$\begin{array}{l}\text { - Siswa dapat menyebutkan alat- } \\
\text { alat yang dapat digunakan untuk } \\
\text { istinja }\end{array}$} \\
\hline \multicolumn{6}{|l|}{$\begin{array}{l}\text { - Siswa dapat menjelaskan tentang } \\
\text { alat yang bias dipakai sebagai } \\
\text { alat penyamak }\end{array}$} \\
\hline \multicolumn{6}{|l|}{$\begin{array}{l}\text { - Siswa dapat menjelaskan } \\
\text { definisi najis }\end{array}$} \\
\hline \multicolumn{6}{|l|}{$\begin{array}{l}\text { - Siswa dapat menyebutkan } \\
\text { macam-macam najis }\end{array}$} \\
\hline $\begin{array}{l}\text { - Siswa dapat menjelaskan cara } \\
\text { bersuci dari hadats dan najis }\end{array}$ & & & & & \\
\hline
\end{tabular}




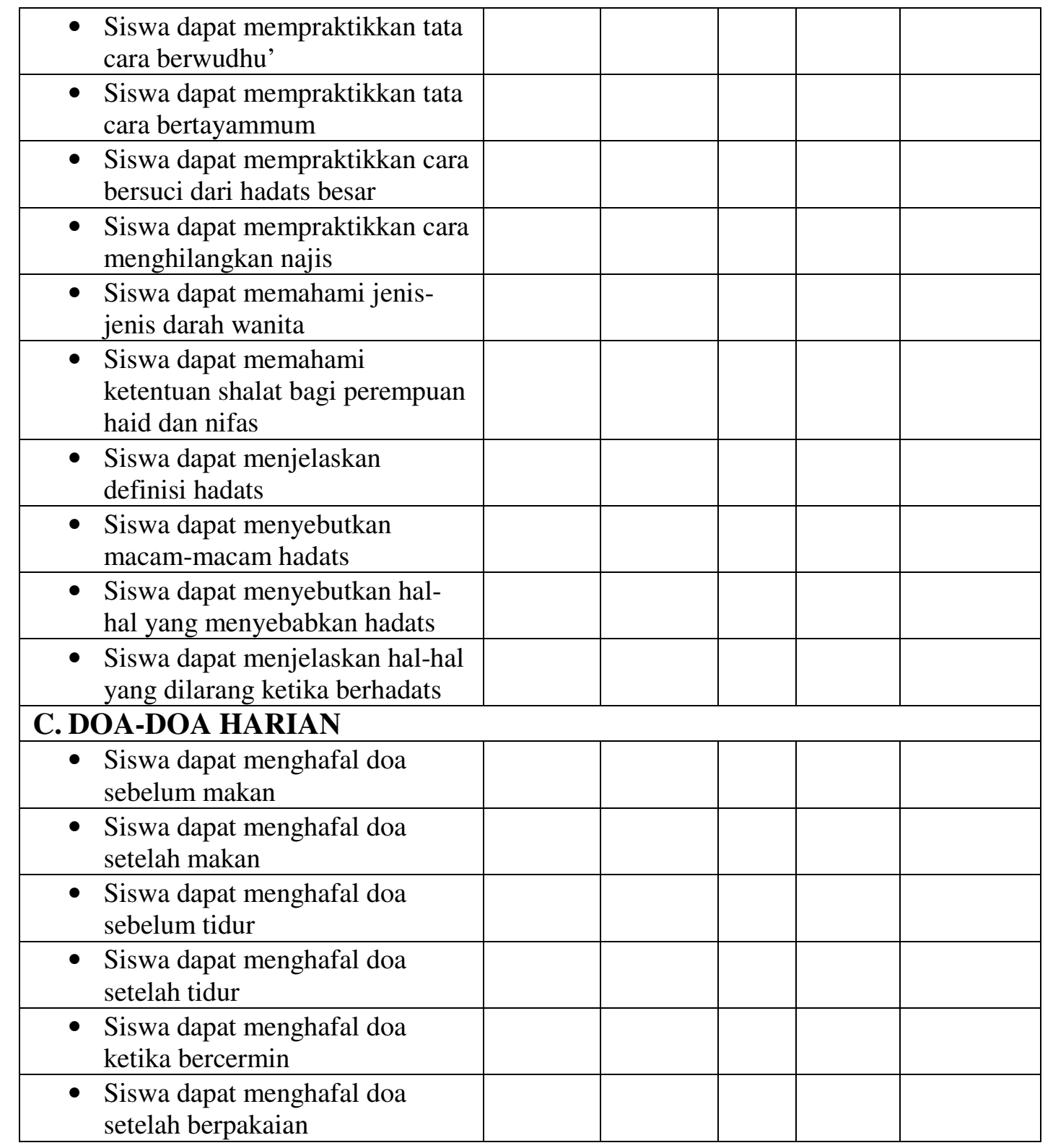

Table: 2

\begin{tabular}{|c|c|c|c|c|c|}
\hline \multirow[b]{2}{*}{ Materi Kelas 1 (Semester II) } & \multicolumn{2}{|c|}{ Nilai } & \multirow[b]{2}{*}{ Tgl. } & \multirow[b]{2}{*}{ Bulan } & \multirow{2}{*}{$\begin{array}{c}\text { Paraf } \\
\text { Pembina }\end{array}$} \\
\hline & Tuntas & $\begin{array}{c}\text { Tidak } \\
\text { Tuntas }\end{array}$ & & & \\
\hline \multicolumn{6}{|l|}{ A. AQIDAH } \\
\hline \multicolumn{6}{|l|}{$\begin{array}{l}\text { - Siswa dapat menyebutkan } \\
\text { pengertian iman kepada } \\
\text { Malaikat Allah }\end{array}$} \\
\hline $\begin{array}{l}\text { - Siswa dapat menjelaskan } \\
\text { pengertian iman kepada } \\
\text { Malaikat Allah } \\
\end{array}$ & & & & & \\
\hline - Siswa dapat menyebutkan & & & & & \\
\hline
\end{tabular}




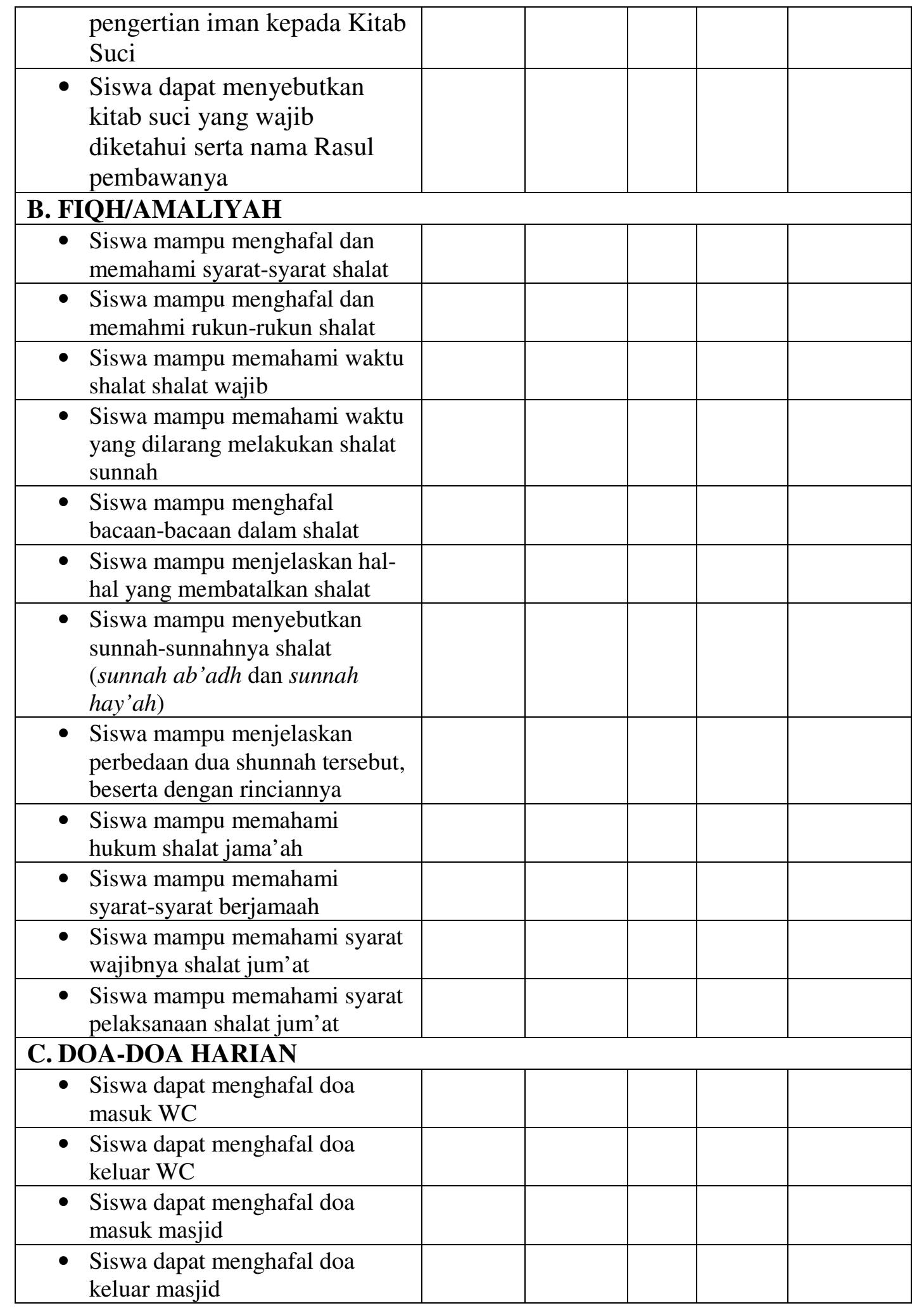


Table:3

\begin{tabular}{|c|c|c|c|c|c|}
\hline \multirow[b]{2}{*}{ Materi Kelas 2 (Semester I) } & \multicolumn{2}{|c|}{ Nilai } & \multirow[b]{2}{*}{ Tgl. } & \multirow[b]{2}{*}{ Bulan } & \multirow[b]{2}{*}{$\begin{array}{c}\text { Paraf } \\
\text { Pembina }\end{array}$} \\
\hline & Tuntas & $\begin{array}{c}\text { Tidak } \\
\text { Tuntas }\end{array}$ & & & \\
\hline \multicolumn{6}{|l|}{ A. AQIDAH } \\
\hline \multicolumn{6}{|l|}{$\begin{array}{l}\text { - Siswa dapat menyebutkan } \\
\text { pengertian iman kepada Rasul } \\
\text { Allah }\end{array}$} \\
\hline \multicolumn{6}{|l|}{$\begin{array}{l}\text { - Siswa dapat menghafal empat } \\
\text { sifat wajib, empat sifat mustahil, } \\
\text { dan satu sifat jaiz bagi Rosul } \\
\text { Allah }\end{array}$} \\
\hline \multicolumn{6}{|l|}{$\begin{array}{l}\text { - Siswa dapat menjelaskan } \\
\text { pengertian iman kepada Hari } \\
\text { Akhir }\end{array}$} \\
\hline \multicolumn{6}{|l|}{$\begin{array}{l}\text { - Siswa dapat menyebutkan dan } \\
\text { menjelaskan hal-hal yang } \\
\text { berkaitan dengan Hari Akhir }\end{array}$} \\
\hline \multicolumn{6}{|l|}{ B. FIQH/AMALIYAH } \\
\hline \multicolumn{6}{|l|}{$\begin{array}{l}\text { - Siswa dapat memahami dasar } \\
\text { hukum qashar shalat }\end{array}$} \\
\hline \multicolumn{6}{|l|}{$\begin{array}{l}\text { - Siswa dapat memahami hukum } \\
\text { mengqashar shalat }\end{array}$} \\
\hline \multicolumn{6}{|l|}{$\begin{array}{l}\text { - Siswa dapat mempraktikkan } \\
\text { qashar shalat }\end{array}$} \\
\hline \multicolumn{6}{|l|}{$\begin{array}{l}\text { - Siswa dapat memahami } \\
\text { pengertian shalat jama' }\end{array}$} \\
\hline \multicolumn{6}{|l|}{$\begin{array}{l}\text { - Siswa dapat memahami hukum } \\
\text { shalat jama' }\end{array}$} \\
\hline \multicolumn{6}{|l|}{$\begin{array}{l}\text { - Siswa dapat mengetahui macam- } \\
\text { macam shalat jama', beserta } \\
\text { dengan syarat-syaratnya }\end{array}$} \\
\hline \multicolumn{6}{|l|}{$\begin{array}{l}\text { - Siswa dapat memahami syarat- } \\
\text { syarat sholat jama' qashar }\end{array}$} \\
\hline \multicolumn{6}{|l|}{$\begin{array}{l}\text { - Siswa dapat mempraktekkan } \\
\text { sholat jama' qashar dengan baik } \\
\text { dan benar }\end{array}$} \\
\hline \multicolumn{6}{|l|}{$\begin{array}{l}\text { Siswa dapat memahami syarat- } \\
\text { syarat sholat bagi yang tidak } \\
\text { mampu berdiri tegak }\end{array}$} \\
\hline \multicolumn{6}{|l|}{$\begin{array}{l}\text { - Siswa dapat mempraktikkan tata } \\
\text { cara shalat bagi yang tidak } \\
\text { mampu berdiri }\end{array}$} \\
\hline \multicolumn{6}{|l|}{$\begin{array}{l}\text { - Siswa dapat menyebutkan cara } \\
\text { merawat jenazah }\end{array}$} \\
\hline $\begin{array}{l}\text { - Siswa dapat mempraktikan tata } \\
\text { cara shalat jenazah }\end{array}$ & & & & & \\
\hline
\end{tabular}




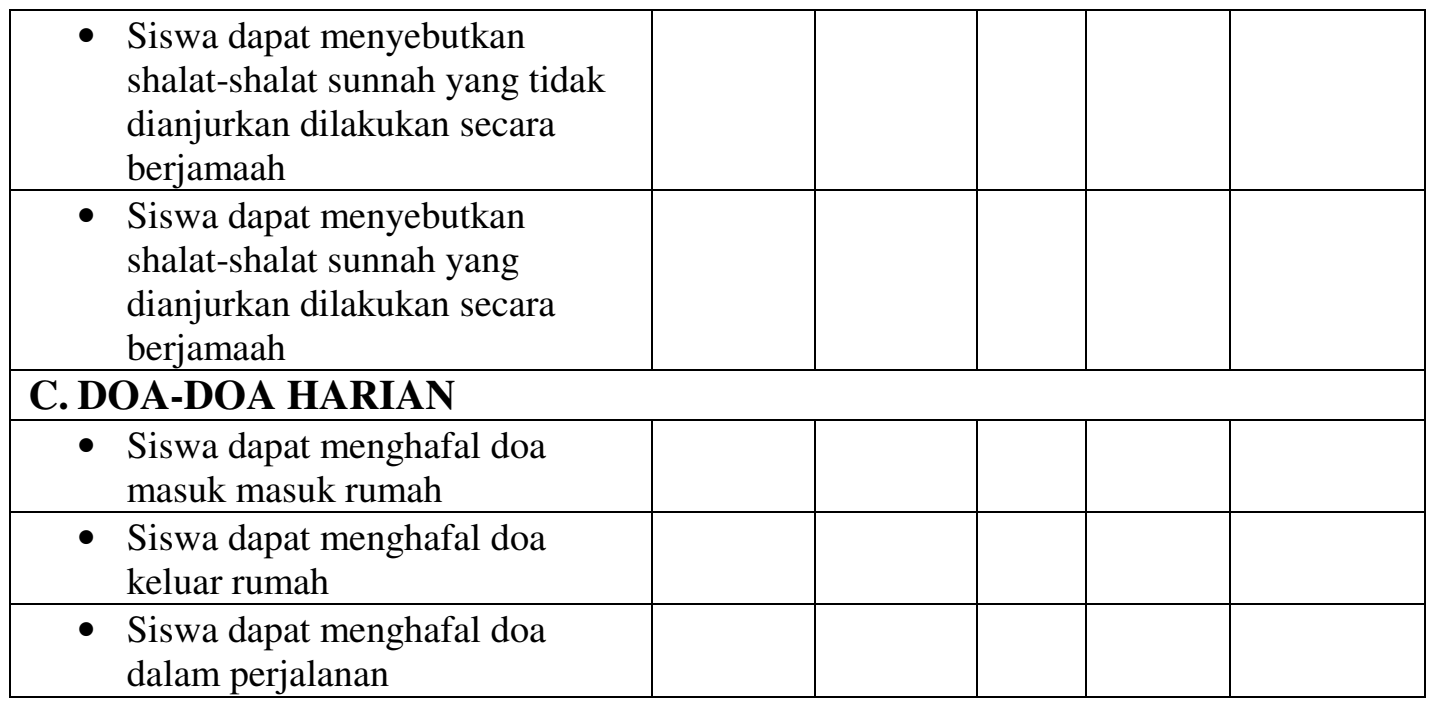

Table: 4

\begin{tabular}{|c|c|c|c|c|c|}
\hline \multirow[b]{2}{*}{ Materi Kelas 2 (Semester II) } & \multicolumn{2}{|c|}{ Nilai } & \multirow[b]{2}{*}{ Tgl. } & \multirow[b]{2}{*}{ Bulan } & \multirow[b]{2}{*}{$\begin{array}{c}\text { Paraf } \\
\text { Pembina }\end{array}$} \\
\hline & Tuntas & $\begin{array}{c}\text { Tidak } \\
\text { Tuntas }\end{array}$ & & & \\
\hline \multicolumn{6}{|l|}{ A. AQIDAH } \\
\hline \multicolumn{6}{|l|}{$\begin{array}{l}\text { - Siswa dapat menyebutkan } \\
\text { pengertian iman kepada qadha' } \\
\text { dan qadar }\end{array}$} \\
\hline $\begin{array}{l}\text { - Siswa dapat menyebutkan } \\
\text { perbedaan antara qadha' dan } \\
\text { qadar }\end{array}$ & & & & & \\
\hline \multicolumn{6}{|l|}{ B. FIQH/AMALIYAH } \\
\hline $\begin{array}{l}\text { - Siswa dapat menyebutkan } \\
\text { syarat-syarat puasa Ramadhan }\end{array}$ & & & & & \\
\hline $\begin{array}{l}\text { - Siswa dapat menyebutkan } \\
\text { rukun-rukun puasa Ramadhan }\end{array}$ & & & & & \\
\hline $\begin{array}{l}\text { - Siswa dapat menyebutkan } \\
\text { sunnah-sunnah puasa Ramadhan }\end{array}$ & & & & & \\
\hline $\begin{array}{l}\text { - Siswa dapat menjelaskan hal-hal } \\
\text { yang dapat membatalkan puasa }\end{array}$ & & & & & \\
\hline $\begin{array}{l}\text { Siswa dapat menyebutkan dan } \\
\text { menjelaskan macam-macam } \\
\text { puasa }\end{array}$ & & & & & \\
\hline $\begin{array}{l}\text { - Siswa dapat menjelaskan } \\
\text { pengertian zakat }\end{array}$ & & & & & \\
\hline $\begin{array}{l}\text { - Siswa dapat menyebutkan } \\
\text { macam-macam zakat }\end{array}$ & & & & & \\
\hline $\begin{array}{l}\text { - Siswa dapat menjelaskan waktu } \\
\text { zakat fitrah }\end{array}$ & & & & & \\
\hline $\begin{array}{l}\text { - Siswa dapat menyebutkan } \\
\text { golongan yang berhak menerima } \\
\text { dan tidak berhak menerima zakat }\end{array}$ & & & & & \\
\hline
\end{tabular}




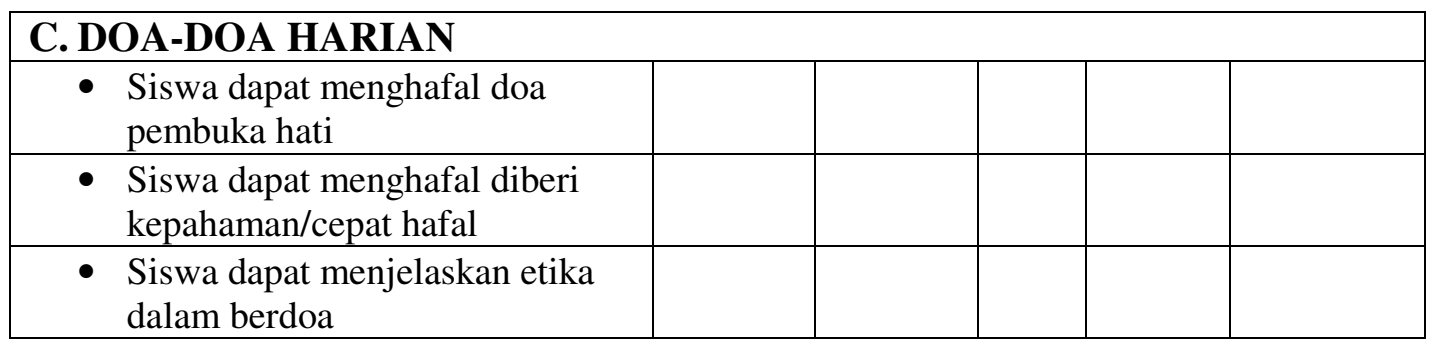

\begin{tabular}{|c|c|c|c|c|c|}
\hline \multirow[b]{2}{*}{ Materi Kelas IX (Semester I) } & \multicolumn{2}{|c|}{ Nilai } & \multirow[b]{2}{*}{ Tgl. } & \multirow[b]{2}{*}{ Bulan } & \multirow{2}{*}{$\begin{array}{c}\text { Paraf } \\
\text { Pembina }\end{array}$} \\
\hline & Tuntas & \begin{tabular}{|c|} 
Tidak \\
Tuntas \\
\end{tabular} & & & \\
\hline \multicolumn{6}{|l|}{ A. Al-Qur'an } \\
\hline \multicolumn{6}{|l|}{$\begin{array}{l}\text { - Siswa menghafal QS. At- } \\
\text { Takatsur }\end{array}$} \\
\hline \multicolumn{6}{|l|}{$\begin{array}{l}\text { - Siswa menghafal QS. Al- } \\
\text { Qari'ah }\end{array}$} \\
\hline \multicolumn{6}{|l|}{$\begin{array}{l}\text { - Siswa mampu membaca dengan } \\
\text { baik dan benar Salah Satu surat } \\
\text { dalam Al-Qur'an }\end{array}$} \\
\hline \multicolumn{6}{|l|}{$\begin{array}{l}\text { - Siswa mampu menulis beberapa } \\
\text { ayat Al-Qur'an dengan baik dan } \\
\text { benar }\end{array}$} \\
\hline \multicolumn{6}{|l|}{ B. FIQH/AMALIYAH } \\
\hline \multicolumn{6}{|l|}{$\begin{array}{l}\text { - Siswa mampu mempraktekkan } \\
\text { sholat jum'at dan menghafal } \\
\text { bacaan Bilal }\end{array}$} \\
\hline \multicolumn{6}{|l|}{$\begin{array}{l}\text { - Siswa mampumempraktekkan } \\
\text { sholat rawatib }\end{array}$} \\
\hline \multicolumn{6}{|l|}{$\begin{array}{l}\text { - Siswa mampu mempraktekkan } \\
\text { sholat Jama' dan sholat Qoshor }\end{array}$} \\
\hline \multicolumn{6}{|l|}{$\begin{array}{l}\text { - Siswa mampu mempraktekkan } \\
\text { sholat jenazah dan sholat ghaib }\end{array}$} \\
\hline \multirow[b]{2}{*}{ Materi Kelas IX (Semester II) } & \multicolumn{2}{|c|}{ Nilai } & \multirow[b]{2}{*}{ Tgl. } & \multirow[b]{2}{*}{ Bulan } & \multirow[b]{2}{*}{$\begin{array}{c}\text { Paraf } \\
\text { Pembina }\end{array}$} \\
\hline & Tuntas & \begin{tabular}{|c|} 
Tidak \\
Tuntas \\
\end{tabular} & & & \\
\hline \multicolumn{6}{|l|}{ C. Al-Qur'an } \\
\hline \multicolumn{6}{|l|}{ - Siswa menghafal QS. Al-Adiyat } \\
\hline \multicolumn{6}{|l|}{$\begin{array}{l}\text { - Siswa menghafal QS. Al- } \\
\text { Zalzalah } \\
\end{array}$} \\
\hline \multicolumn{6}{|l|}{$\begin{array}{l}\text { - Siswa mampu membaca dengan } \\
\text { baik dan benar Salah Satu surat } \\
\text { dalam Al-Qur' an }\end{array}$} \\
\hline \multicolumn{6}{|l|}{$\begin{array}{l}\text { - Siswa mampu menulis beberapa } \\
\text { ayat Al-Qur'an dengan baik dan } \\
\text { benar }\end{array}$} \\
\hline \multicolumn{6}{|l|}{ D. FIQH/AMALIYAH } \\
\hline - Siswa mampu mempraktekkan & & & & & \\
\hline
\end{tabular}




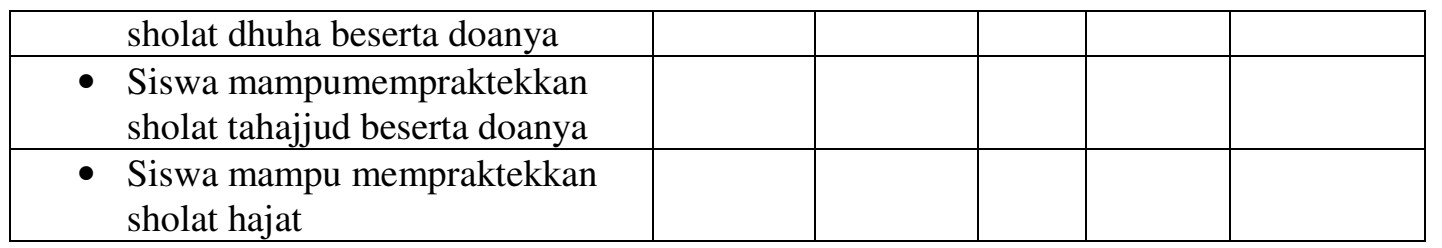

Sumber: Hasil penelitian, di SMP Nurul Jadid Paiton 2018

Penguatan Pendidikan Agama Islam melalui hafalan furudhul ainiyah meliputi beberapa materi diantaranya materi aqidah, fiqih atau amaliyah dan Doa-doa harian untuk kelas VI dan kelas VII semester 1 dan 2, sementara untuk kelas IX semester 1 dan 2 mencakup materi tentang Al-Qur'an dan fiqih atau amaliyah. Meskipun dengan waktu PAI yang hanya 2 jam dalam satu minggu dengan adanya penguatan berupa hafalan Furudhul ainiyah maka, siswa atau siswi SMP Nurul Jadid diharapkan tidak hanya mumpuni dalam hal ilmu umum saja tetapi juga mumpuni dalam hal ilmu Agama Islam.

Berdasarkan uraian diatas, Muhaimin mengungkapkan pendidikan agama Islam yang jam pelajarannya relatif terbatas dapat ditambah dan dikembangkan. Disamping itu, meningkatnya kesadaran siswa akan rasa kebutuhan terhadap pembinaan keagamaan dan rasa memiliki terhadap kegiatan keagamaan yang tumbuh dilingkungan masyarakat.. ${ }^{7}$

Penguatan pembelajaran pendidikan agama Islam di luar kelas merupakan tanggung jawab seluruh umat Islam, sebagaimana yang telah disampaikan Muhammad Zein kepada umat Islam di Indonesia agar turut serta

\footnotetext{
${ }^{7}$ Muhaimin, Wacana Pengembangan Pendidikan Islam, (Yogyakarta: Pustaka Pelajar, 2004), hal. 305
} 
dalam menyelenggarakan atau menguatkan lembaga-lembaga pendidikan agama Islam yang ada. ${ }^{8}$

Dalam pelaksanaannya, siswa dituntut untuk menuntaskan materi furudhul Ainiyah yang berupa hafalan dan dijadikan sebagai syarat bagi siswa untuk mengikuti ujian dan kenaikan kelas, jadi bagi siswa ataupun siswi yang tidak menuntaskan hafalannya maka bisa dipastikan siswa maupun siswi tersebut tidak bisa mengikuti ujian semester, baik ganjil maupun genap, bahkan terancam tidak naik kelas.

Waktu pelaksanaan setoran hafalan furudhul ainiyah dilaksanakan pada hari kamis dari jam 7.30. wib sampai jam $13.00 \mathrm{wib}$, namun juga bisa dilaksanakan ketika jam istirahat serta pada malam hari dimalam Jum'at dan malam selasa.

Sementara bagi siswa maupun siswi yang tidak bisa baca tulis Al-Qur'an maka, tidak dikenakan keawajiban menghafal namun, mendapatkan pembinaan khusus terkait baca tulis Al-quran yang dilakukan oleh oleh bagian Koordinator keagamaan siswa. Disadari atau tidak dalam pelaksanaannya ada beberapa kendala yang dihadapi diantaranya, terbatasnya waktu, banyaknya materi yang harus dihafal oleh siswa atau siswi,kurangnya tenaga pengajar yang berkaitan dengan pelaksaan hafalan furudhul ainiyah.

\footnotetext{
${ }^{8}$ Muhammad Zein, Metodologi Pengajaran Agama, (Yogyakarta: AK Group, 1995), hal. xi
} 


\section{KESIMPULAN DAN SARAN}

\section{A. KESIMPULAN}

Dari pemaparan di atas dapat diperoleh kesimpulan bahwa:

1. Perlunya penguatan dalam PAI salah satunya dengan model hafalan Furudhul Ainiyah, mengingat waktu yang diberikan hanya 2 jam dalam seminggu;

2. Salah satu lembaga yang melakukan penguatan terhadap mata pelajaran Pendidikan Agama Islam adalah SMP Nurul Jadid Paiton Probolinggo, yaitu dengan model hafalan Furudhul Ainiyah

3. Materi yang dalam Furudhul Ainiyah meliputi beberapa materi diantaranya materi aqidah, fiqih atau amaliyah dan Doa-doa harian untuk kelas VI dan kelas VII semester 1 dan 2, sementara untuk kelas IX semester 1 dan 2 mencakup materi tentang Al-Qur'an dan fiqih atau amaliyah.

4. Siswa ataupun siswi diwajibkan untuk menuntaskan hafalan Furudhul Ainiyah, karena merupakan syarat untuk mengikuti ujian semester, dan menjadi syarat kenaikan kelas.

\section{B. SARAN}

Artikel penelitian ini masih sangat jauh dari kesempurnaan.oleh karena itu saran dan kritik yang konstruktif akan kami terima demi perbaikan artikel ini. 


\section{DAFTAR PUSTAKA}

Lexy J. Metodologi. 2000. Penelitian Kualitatif. Bandung: PT. Remaja Rosda Karya,

> Munardji. 2004. ilmu pendidikan Islam. Jakarta, PT. Bina ilmu.

$>$ Arief, Armai. 2002. Pengantar Ilmu dan Metodologi Pendidikan Islam. Jakarta: Ciputat Pers.

$>$ Ramayulis. 2002. Ilmu Pendidikan Islam. Jakarta : kalam mulia.

> Zakiah Daradjat. 2011. Ilmu Pendidikan Islam. Jakarta: PT Bumi Aksara.

> Muhaimin, 2004. Wacana Pengembangan Pendidikan Islam, Yogyakarta: Pustaka Pelajar,

> Muhammad Zein, 1995. Metodologi Pengajaran Agama, Yogyakarta: AK Group.

Baharun, H., \& Mundiri, A. (2011). Metodologi Studi Islam: Percikan Pemikiran Tokoh Dalam Membumikan Agama. Ar-Ruzz Media (1st ed.). Yogyakarta: Ar-Ruzz Media. Mundiri, A. (2012). PENDIDIKAN TEKNOHUMANISTIK BERBASIS CORE ETHICAL VALUES. At-Tajdid, 1(1), 37-47.

Mundiri, A., \& Zahra, I. (2017). CORAK REPRESENTASI IDENTITAS USTADZ DALAM PROSES TRANSMISI PENDIDIKAN KARAKTER DI PESANTREN. Jurnal Pendidikan Islam, Vol. 2, No, 21-35. 